\title{
Model Triple Bottom Menuju Kinerja Keuangan
}

\section{Triple Bottom Model Towards Financial Perfomance Hermanto}

\author{
Jurusan Akuntansi Fakultas Ekonomi dan Bisnis Universitas Esa Unggul, Indonesia
}

Diterima: 08 Agustus 2021 Direview: 08 Agustus 2021 Disetujui: 28 September 2021

*Coresponding Email: Hermanto@esaunggul.ac.id

\section{Abstrak}

Penelitian dilakukan untuk mengidentifikasi pengaruh Sustainability Report, Kinera Lingkungan-GRI200, Kinerja Ekonomi-GRI300, dan Kinerja Sosial-GRI400 berhubungan dengan Return on Asset pada organisas masuk dalam nominasi ASSRAT tahun 2017- 2019 baik secara bersama- sama maupun masingmasing variabel. Metode sampel judgement sampling. Sampel penelitian ini adalah 20 entitas perusahaan masuk kedalam nominasi ASSRAT dan terigister di Bursa Efek Indonesia (BEI) dengan jumlah sampel 60 data. Jenis data berupa sekunder dari sumberi informasi keuangan dan annual report. Metode analisis regresi linear berganda. Temuan penelitian ini adalah berdasarkan hasil uji $\mathrm{f}$, variabel independent berpengaruh secara simultan terhadap Retun on Asset. Secara parsial Kinerja Lingkungan- GRI 200 dan Kinerja Ekonomi- GRI 300 berdampak positif terhadap Return on Asset, Perusahaan dalam yang masuk dalam nominasi ASSRAT lebih memperhatikan aspek Kinerja Ekonomi diperusahaan sehingga paradigma old Corporate Relation masih diadopsi oleh perusahaan- perusahaan yang masuk nominasi ASSRAT. Perusahaan pada nominasi ASSRAT tidak hanya memperhatikan keuntungan semata namun tetap memberikan perhatian kepada aspek kinerja lingkungan sehingga dapat meningkatkan citra perusahaan dimata stakeholders.

Kata Kunci: Return on Asset, Sustainability Report, GRI 200, GRI 300, GRI400

\section{Abstract}

The study conducted to identify effect of Sustainability Report, Environmental Performance-GRI200, Economic Performance-GRI300, and Social Performance-GRI400 related to Return on Assets in organizations included in the ASSRAT nominations for 2017-2019 both together and individually. Judgment sampling sampling method. The sample of this research is 20 corporate entities included in the ASSRAT nomination and registered on the Indonesia Stock Exchange (IDX) with a sample of 60 data. The type of data is secondary from sources of financial information and annual reports. Multiple linear regression analysis method. The findings of this study are based on the results of the $f$ test, the independent variable has a simultaneous effect on Return on Assets. Partially Environmental Performance- GRI 200 and Economic Performance- GRI 300 have a positive impact on Return on Assets, Companies that are included in the ASSRAT nomination pay more attention to aspects of the company's Economic Performance so that the old Corporate Relations paradigm is still adopted by companies that are nominated by ASSRAT. Companies in the ASSRAT nomination do not only pay attention to profits but also pay attention to aspects of environmental performance so that they can improve the company's image in the eyes of stakeholders. Keywords: Return on Asset, Sustainability Report, GRI 200, GRI 300, GRI400

How to Cite: Hermanto. (2021). Model Triple Bottom Menuju Kinerja Keuangan, Jurnal Akuntansi dan Bisnis: Jurnal Program Studi Akuntansi 7(2): 166-179 


\section{PENDAHULUAN}

Pemanfaatan dalam sumber daya alam merupakan proses yang dapat menimbulkan penurunan kualitas hidup lingkungan serta berdampak negatif seperti mengakibatkan kehabisan sumber daya alam, limbah yang muncul pada tanah, air, udara serta konflik sosial yang terjadi (Manik, 2016). Pencemaran lingkungan merupakan sebuah isu utama yang sering dibahas dalam salah perusahaan dan para pemangku kepentingan menuntut perusahaan untuk memberikan pertanggungjawaban sosial bagi lingkungan dan masyarakat sekitar lingkungan (Mulyaningsih \& Hermina, 2017). Dalam mengimplementasikan pembangunan berkelanjutan (sustainable development) serta mempublikasikan pelaksanaannya dapat menjadi tujuan penting untuk kelangsungan usaha perusahaan (UNGC, 2019). Konsep keberlanjutan yang dikenal dengan Tripple Bottom Line 3P merupakan pandangan bahwa perusahaan tidak boleh berfokus untuk memperkaya stockholder dan stakeholder dalam perusahaan, dan tetap memperhatikan kesejahteraan masyarakat sekitar perusahaan (people) serta menjaga pelestarian lingkungan (planet) (Porter \& Kramer, 2006).

Laporan Keberlanjutan (Sustainability Report) menginformasikan perusahaan melakukan praktik pelaporan perusahaan secara terbuka dan transparan terhadap dampak sosial, ekonomi, dan lingkungan, serta memiliki hubungan membaik atau memburuk terhadap pembangunan berkelanjutan, serta transparansi dan akuntabilitas organisasi yang lebih besar (GRI, 2016). Pengungkapan Sustainability Report terus berkembang serta memperoleh respon positif secara global hal ini dikarenakankan dukungan oleh seluruh lapisan masyarakat. Dalam praktik pelaporan sustainability report di negara Indonesia, telah mengimplementasikan praktik sustainability report kedalam aturan- aturan regulasi pemerintah seperti mengeluarkan peraturan Nomor 51/P0JK.03/2017 tentang penerapan keuangan berkelanjutan bagi lembaga jasa keuangan, emiten, dan perusahaan publik (OJK, 2017). Hal ini mempu mendorong pembangunan berkelanjutan dalam mengedepankan keselarasan antara aspek social, lingkungan hidup, dan ekonomi.

Pelaporan keberkelanjutan memiliki manfaat bagi entitas perusahaan untuk melakukan proses peningkatan investasi maupun menghasilkan pendanaan, serta menjalin kemitraan (Kompas.com, 2015). Kemampuan perusahaan dalam melakukan komunikasi atas kegiatan dan kinerja perusahaan dapat mampu memberikan kontribusi yang cukup efektif dengan melakukan Sustainability Report dinilai sebagai salah satu proxy transparansi, akuntanbilitas, responsibilitas, serta fairness kepada seluruh jajaran stakeholders-nya sehingga meningkatkan reputasi serta kinerja perusahaan (Ernst \& Young, 2014).

Menurut Lee, (2017) menyatakan Sustainability Report merupakan sebuah aspek economic, social, dan environment serta memberikan dampak signifikan terhadap performance keuangan. Sedangkan menurut Wibowo \& Faradiza, (2014) mengungkapkan laporan keberlanjutan yang dilaksanakan perusahaan, tidak memiliki dampak terhadap performance keuangan. Menurut Nelmida et al., (2020) pengungkapan Sustainability Report mampu memberikan pengaruh positif terhadap profitabilitas, pengungkapan aspek environment performance tidak berdampak terhadap financial perfomance, dan pengungkapan aspek sosial dalam laporan keberlanjutan memiliki dampak negatif signifikan terhadap financial performance. Penelitian Eliyana \& Subakir, (2020) transparansi Sustainability Report atas environment perfomance, economic performance, dan social performance mampu menunjukkan secara dominan economic performance yang berpengaruh terhadap profitabilitas. 
Berdasarkan penelitian terdahulu yang dilakukan oleh Lee pada tahun 2017 yang membahas mengenai isu kelangsungan hidup (Lee, 2017), maka dinilai penting dalam pengungkapan Sustainability Report bagi penerapan pelaporan sustainability report, serta ditemukan research gap antara peneliti terdahulu yang telah melakukan penelitian terlebih dahulu. Maka penelitian ini memiliki tujuan yang sangat penting dalam melakukan pengujian serta melakukan analisis kembali atas pengungkapan sustainability report pada organisasi pada negara Indonesia sehingga dapat memaksimalkan keuntungan entitas di Indonesia.

Teori Stakeholders, Teori Stakeholder telah berkembang dengan pesat. Kemunculannya diidentifikasi Freeman (2010: 3-4) sebagai bentuk tanggungjawab terhadap penciptaan nilai serta timbunya kekuasaan kapital etis dan presepsi manajerial. Secara jauh dapat dinyatakan bahwa teori stakeholder mampu memberikan hubungan antara suatu entitas bisnis dengan bagian suatu kelompok dan/atau individu yang saling memberikan pengaruh sehingga problem tersebut dapat segera teratasi. Dengan kata lain, timbulnya fenomena-fenomena tersebut dapat terselesaikan apabila memiliki hubungan relasi yang baik dan transparan antara manajer dan pemangku kepentingan (Ardiyasa, 2021). Manajemen organisasi melakukan kegiatan organisasi dianggap penting oleh stakeholder serta memberikan informasi kembali atas kegiatan aktivitas-aktivitas yang telah berjalan kepada stakeholder. Teori stakeholder mempunyai hak untuk mengakomodir informasi mengenai aktivitas organisasi. Selain itu, organisasi akan melakukan pengungkapan informasi secara sukarela tentang environment performance, social, dan intelektual untuk mengakomodir ekspektasi para stakeholder. memiliki opini yang memiliki hubungan pengaturan atau pelaksanaan yang mampu memberikan arah atas struktur, praktik dan sikap, jika dilaksanakan secara berkesinambungan mampu membangun filosofi stakeholder management.

Stakeholders theory mengalami perubahan paradigma pendekatan organisasi melakukan kegiatan usaha dari pandangan zaman dahulu menjadi pandangan zaman modern. Perusahaan yang memiliki pandangan zaman dahulu lebih menekankan kegiatan perusahaan secara tersendiri tanpa memberikan hubungan kesatuan diantara pelaksananya, sedangkan perusahaan yang memiliki padangan modern selalu mengutamakan kolaborasi perusahaan dengan para pemangku kepentingannya sehingga membuat perusahaan tidak mementingkan perusahaan sebagai bagian organisasi yang terpisah dari ekosistem masyarakat. Perubahan ini mampu membuat tujuan dan arah perusahaan dapat meningkatkan keuntungan perusahaan namun terhadap pencapaian pembangunan yang berkelanjutan (sustainability development) (Yuliani \& Taringan, 2014).

Sustainability Report, Global Reporting Initiative (GRI) mengartikan Sustainability Report praktik reporting perusahaan secara transparan mengenai akibat operasional perusahaan terhadap lingkungan, ekonomi, dan sosial, dan karena itu juga termasuk kontribusi baik atau buruk atas tujuan pembangunan berkelanjutan, sehingga memungkinkan akuntanbilitas dan transparansi organisasi yang lebih besar (GRI, 2016). Elkington, (1997) mendefinisikan Sustainability Report tidak hanya mencantumkan financial perfomance namun dapat mencerminkan informasi yang bersifat non financial yang berisi informasi aktivitas kegiatan lingkungan dan kegiatan sosial yang memiliki dampak atas pertumbuhan perusahaan secara berkelanjutan (sustainable performance).

Manfaat Sustainability Report, Manfaat sustainability report berdasarkan acuan dari pedoman GRI (2011) yaitu: (a) sebagai bentuk tolok ukur performance organisasional dengan mengedepankan norma, hukum, undang-undang, performance standard, dan prinsip sukarela; (b) menunjukan loyalitas organisasi dalam menerapkan sustainable 
development; dan (c) membedakan performance organisasional dari waktu ke waktu. Perusahaan harus mampu menjalin relasi antara perusahaan dengan stakeholders serta mampu mengakomodir keinginan dan kebutuhan stakeholders, yang mempunyai kemampuan terhadap resources yang akan dipakai untuk kegiatan entitas, seperti employee, Customer, dan owner (Wahab, 2020). Hal tersebut itu, going concern organisasi memiliki ketergantungan support dari para stakeholder sehingga kegiatan perusahaan dilaksanakan untuk mencari support tersebut.

Prinsip Pengungkapan Sustainability Report, GRI menetapkan prinsip pelaporan dan memberikan laporan panduan standar. Prinsip pelaporan bersifat esensial untuk mencapai Sustainability Report yang memiliki kualitas tinggi. Prinsip-Prinsip Pelaporan terdapat dalam GRI 101 yang dibagi menjadi 2 (dua) bagian yaitu pendefinisian reporting content dan quality reporting (GRI, 2016). Pedoman dalam menentukan content reporting mampu menjelaskan apa saja yang diterapkan untuk mampu melakukan identifikasi atas isi laporan yang wajib memperhatikan impact atas, harapan dan aktivitas, serta kepentingan yang substantif dari para stakeholders. Pedoman ini disusun guna menentukan konten laporan, yakni: (a) Inklusivitas stakeholders adalah perusahaan mampu mengidentifikasi kepentingan para stakeholders serta menjelaskan mekanisme organisasi dalam mengakomodir harapan dan kepentingan stakeholders. (b) sustainability context adalah reporting wajib menginformasikan organization performance secara sustainability context yang lebih luas dan transaparan. (c) materiality level adalah reporting mampu meliputi aspek berdampak environment, economic, dan social yang mampu memberikan dampak langsung kepada organisasi atau secara substansial mampu dapat mempengaruhi penilaian dan keputusan stakeholders. (d) Completeness yaitu reporting wajib mencakup aspek material dan boundary, serta mampu memberikan impact terhadap lingkungan, ekonomi, dan social yang memiliki dampak tinggi, serta memberikan acuan pemangku kepentingan dapat melakukan value atas performance perusahaan dalam suatu periode laporan. Prinsip dalam pelaksanaan atas kualitas laporan yang mampu memberikan petunjuk berupa langkah- langkah yang dapat dilakukan guna menjamin kualitas suatu informasi dari laporan keberlanjutan, merupakan komponen penyampaian yang tepat. Informasi yang memiliki Kualitas baik yang dapat memberikan dasar para stakeholders dalam membuat suatu performance value yang logic serta dapat mengambil langkah-langkah yang tepat yakni: keseimbangan, akurasi, kejelasan, komparabilitas, keandalan dan ketepatan waktu.

Teori Legitimasi (Legitimacy Theory), Penyusunan dan pelaporan Sustainability Report Menurut Deegan, (2006) dalam teori legitimasi menerangkan organisasi secara terus menerus berusaha dalam memastikan kegiatan perusahaan telah beroperasi dengan memiliki batas dan norma yang dijunjung oleh lingkungan sekitar dan perusahaan juga terus berusaha dalam memastikan aktivitasnya bisa dapat diperkenankan oleh pihak luar sebagai kegiatan yang benar. Dasar dari teori legitimasi merupakan perjanjian sosial yang telah disepakati oleh perusahaan dengan lingkungan sekitar perusahaan, serta di wilayah beroperasinya organisasi dan masyarakat telah menyetujui perusahaan dapat menggunakan sumber daya dalam menjalankan kegiatan bisnisnya (Chariri \& Ghozali, 2007). Teori legitimasi memainkan peran sebagai faktor yang dapat dibenarkan untuk pengungkapan informasi sosial dan lingkungan (Burlea \& Popa, 2013). Legitimasi adalah fundamental dan menjadi faktor bagi perusahaan dalam mengembangkan perusahaan (Zelditch Jr, 2018). Legitimasi mencerminkan hal yang diinginkan perusahaan dari masyarakat lingkungan sekitar karena legitimasi merupakan resources yang berarti bagi kelangsungan hidup (going concern) (Hadi, 2009). Teori legitimasi sebuah kondisi yang ada atas sebuah sistem nilai entitas kongruen dengan nilai sistem dari masyarakat yang 
luas dimana entitas menjadi salah satu bagiannya (Lindblom, 1994). Ketika ada perbedaan, baik aktual maupun potensi, yang ada diantara kedua sistem nilai, maka akan dapat memberikan ultimatum terhadap legitimasi perusahaan (Deegan \& Unerman, 2006). (Neu et al., 1998) berargumentasi untuk mengurangi kesenjangan legitimasi (legitimation gap) oragnisasi wajib mengkaji aktivitas yang ada di bawah kendali serta mengkaji pengaruh publik memiliki power yang mampu memberikan efek legitimasi kepada perusahaan.

\section{METODE PENELITIAN}

Model Penelitian, ini menggunakan hubungan sebab akibat (kausalitas eksplanatori) yang mengkaji variabel- variabel independent dalam penelitian dengan variabel dependent. Teknik pengambilan sampling purposive sampling dengan beberapa kriteria yang telah dilakukan analisis dan penentuan oleh peneliti berdasarkan penelitian- penelitian sebelumnya dengan kriteria sebagai berikut: aPerusahaan secara konsisten tercatat di Bursa Efek Indonesia selama masa periode penelitian serta masuk dalam nominasi ASRRAT, bPerusahaan yang telah menerbitkan laporan Sustainability Report, dengan mengacu pada pedoman Global Reporting Initiative Tahun 2016.

Teknik pengolahan data menggunakan teknik multiple linear regression yang menggunakan beberapa uji yaitu: ${ }^{a} u j i$ Deskriptif untuk menilai nilai rata- rata, maksimal, minimum serta standar deviasi data yang akan diteliti. bUji normalitas yang berfungsi untuk mengukur data yang akan dilakukan penelitian ini memiliki distribusi yang normal dengan menggunakan standard nilai signifikansi sebesar 0,05 (5\%). cUji Multikolinearitas yang berfungsi melakukan penilaian atas model penelitian pada penelitian ini memiliki hubungan yang kuat antara variabel- variabel terikat dengan variabel bebas. dUji Autokorelasi sebagai dasar untuk menguji korelasi antara satu pengamatan ke pengamatan lainnya. eUji Heterokedastisitas yang merupakan pengujian terhadap model linear atas ketidaksamaan varians dari satu residual ke residual lain. fUji $F$ merupakan pengujian atas model penelitian, pada penelitian ini menggunakan nilai signifikansi dibawah 0,05. gUji t menguji hubungan secara masing- masing antara variabel terikat dengan variabel bebas dengan menggunakan dasar nilai signifikansi dibawah 0,05. hUji Regresi Linear merupakan pengujian atas seberapa besar variabel- variabel independent berpengaruh terhadap variabel dependen, berdasarkan model diatas maka dapat dirumuskan uji regresi linear sebagai berikut:

$\mathrm{ROA}=\mathrm{C}+B 1 *$ Sustainability Report $+B 2 *$ Ekonomi $+B 3 *$ Lingkungan $+B 4 *$ Sosial $+\mathrm{E}$

Berdasarkan history penelitian terdahulu, maka peneliti menggunakan model penelitian dan mengubah variabel dependent menggunakan Return on Asset (ROA) dengan gambar sebagai berikut: 


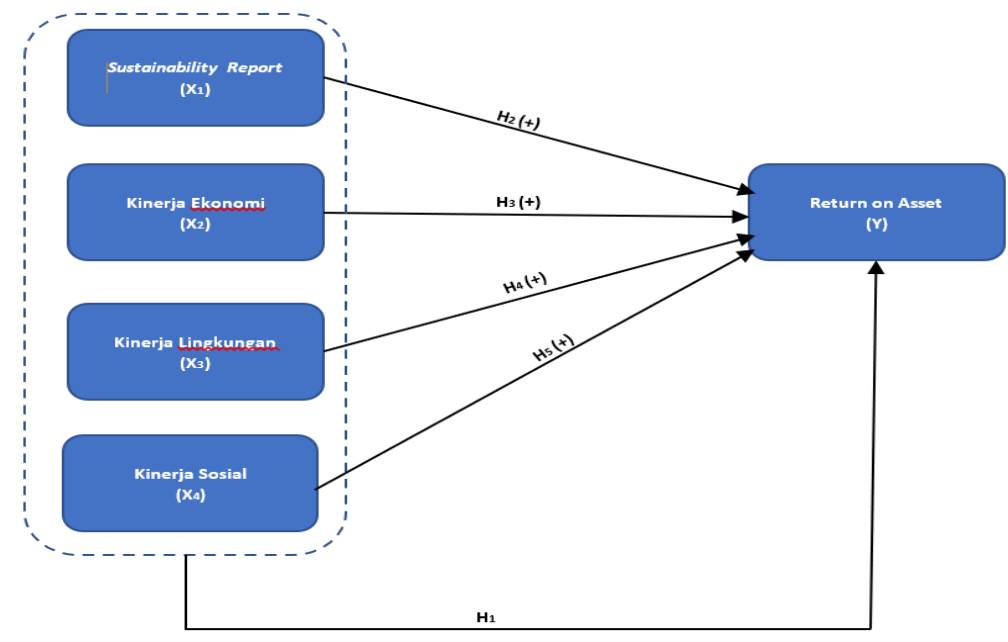

Gambar 1: Model Penelitian

Hubungan Sustainability report, Aspek kinerja ekonomi, Aspek kinerja lingkungan, dan Aspek kinerja sosial terhadap Return on Asset

Perusahaan dalam melakukan kegiatan operasional perusahan harus tetap harus memperhatikan kondisi sekitar perusahaan, dimana dalam melaksanakan kegiatan operasional terdapat proses limbah yang dihasilkan sehingga dapat berdampak buruk bagi lingkungan sekitar perusahaan. Pada zaman sekarang ini stakeholders tidak hanya memperhatikan aspek kinerja perusahaan namun tetap memperhatikan kontribusi terhadap lingkungan baik didalam maupun diluar perusahaan. Berdasarkan kesimpulan diatas peneliti menarik rumusan sebagai berikut:

$\mathrm{H}_{1}$ : Sustainability report, Aspek kinerja ekonomi, aspek kinerja lingkungan, dan aspek kinerja Sosial berpengaruh secara simultan terhadap Return on Asset.

\section{Hubungan Sustainability report berpengaruh terhadap Return on Asset.}

Return on Asset salah satu alat ukur penting dalam menilai kinerja perusahaan serta performance manajemen dalam melakukan pengelolaan resources perusahaan yang ditunjukkan oleh keuntungan yang dihasilkan. Transparansi atas Sustainability Report perusahaan dapat memberikan informasi jelas atas proses operasional perusahaan tidak berorientasi profit yang didapatkan, tetapi juga tetap memperhatikan isu lingkungan dan sosial, sehingga mampu menaikan tingkat kepercayaan stakeholder serta dapat berdampak kepada kenaikan atas value perusahaan melalui kenaikan jumlah investasi serta memiliki dampak pada kenaikan keuntungan perusahaan. Berdasarkan hal diatas dapat ditarik sebuah rumusan sebagai berikut:

$\mathrm{H}_{2}$ : Sustainability report berpengaruh secara positif terhadap Return on Asset.

\section{Hubungan Aspek kinerja ekonomi berpengaruh terhadap Return on Asset.}

Sustainability report pada aspek ekonomi dapat memiliki pengaruh langsung terhadap return on asset. Dalam hal tersebut terjadi dikarenakan pengungkapan atas laporan sustainability reporting dalam aspek kinerja ekonomi perusahaan mampu meningkatkan atas keyakinan potensi modal yang kompetitif dan tingkat investasi yang bersifat low risk kepada stakeholder, khususnya investor dan kreditor yang sangat memperhatikan tingkat pemulangan pinjaman/modal yang diberikan. Dalam penelitian yang baru dilakukan mengatakan penanam modal lebih memilih melakukan investasi pada perusahaan yang transparan dalam melaporkan laporannya dalam hal ini dikarenakan tingkat kepercayaan investor kepada manajemen lebih tinggi dalam mengungkapkan informasi atas keakuratan forecasting, analysis, serta memberikan 
asimetri informasi yang lebih kecil (Ernst \& Young Global Limited, 2013). Adanya paradigma dari investor maupun kreditor, maka diyakini mampu mendorong peningkatan pendanaan pada perusahaan. Pendaanan digunakan perusahaan sebagai dasar keputusan dalam melakukan keputusan investasi asset perusahaan, serta digunakan dalam menghasilkan keuntungan bagi perusahaan. Return on Asset dapat digunakan sebagai tolak ukur dalam efisiensi pengelolaan asset dalam menghasilkan pendapatan, sehingga dapat ditarik rumusan sebagai berikut:

$\mathrm{H}_{3}$ : Aspek kinerja ekonomi berpengaruh secara positif terhadap Return on Asset.

\section{Hubungan Aspek kinerja lingkungan berpengaruh terhadap Return on Asset.}

Dengan pengungkapan laporan sustainability report dengan sub kinerja lingkungan dapat mampu memberikan sebuah bukti empiris atas kegiatan operasional yang dilakukan perusahaan tidak memprioritaskan keuntungan semata tetapi tetap memperhatikan kondisi sekitar perusahaan sehingga dapat meningkatkan citra perusahaan dimata stakeholders sehingga investor dan stakeholders lainnya memiliki tingkat kepercayaan yang tinggi terhadap perusahaan sehingga mampu meningkatkan peningkatan laba perusahaan yang di proxykan melalui Return on Asset. Kondisi ini mengungkapkan sustainability report dapat meningkatkan kepercayaan stakeholders sehingga dapat meningkatkan profit perusahaan. Dalam penelitian Arjowo (2013), dan Safitri (2015) yang menginformasikan sustainability report sub lingkungan memiliki pengaruh terhadap financial performance yang diproxykan dengan variabel Return on Asset dengan arah positif. Berdasarkan diatas dapat ditarik sebuah hipotesis sebagai berikut:

$\mathrm{H}_{4}$ : Aspek kinerja lingkungan berpengaruh secara positif terhadap Return on Asset.

\section{Hubungan Aspek kinerja Sosial berpengaruh terhadap Return on Asset.}

Dalam dimensi sosial memiliki dampak atas kegiaan organisasi terhadap lingkungan sekitar perusahaan, serta mampu menjelaskan dimensi risiko atas hubungan dengan institusi sosial lainnya. Social dimensions terbagi menjadi 4 (empat) aspek, berupa human rights, public, responsibility atas product yang ditawarkan, employee dan pekerjaan layak (Chariri \& Ghozali, 2007). Pengungkapan Responsibility sosial kepada karyawan juga mampu memberikan pengaruh positif bagi stakeholders tidak hanya meningkatkan nilai atas saham perusahaan, dan dapat meningkatkan kompensasi karyawan serta dapat menurunkan tingkat keluar karyawan sehingga dapat berujung pada meningkatnya kinerja perusahaan (Ernst \& Young Global Limited, 2013). Berdasarkan uraian tersebut dapat dirumuskan sebagai berikut.

H5: Aspek kinerja sosial berpengaruh secara positif terhadap Return on Asset.

Variabel Dependent, dalam penelitian ini menggunakan kinerja keuangan perusahaan yaitu Return on Asset, dengan menggunakan perhitungan yaitu:

$$
\text { Return On Asset (ROA) : } \frac{\text { Laba Bersih }}{\text { Total Asset }} \text { X 100\% }
$$

Variabel ini menggunakan skala Rasio.

Variabel Independent, aSustainability Report merupakan praktik pengukuran dan pengungkapan atas aktivitas operasional perusahaan, sebagai bentuk responsibility kepada stakeholder baik internal dan eksternal perihal kinerja organisasi. Variabel ini menggunakan pengukuran sebagai berikut: 


$$
\text { Sustainability Report : } \frac{\text { Total Pengungkapan Sustainability Report Perusahaan }}{\text { Jumlah Indeks Pengungkapan GRI } 2016}
$$

Variabel ini menggunakan skala Rasio.

${ }^{b}$ Kinerja Ekonomi- GRI 200, merupakan pelaporan kinerja ekonomi perusahaan pada laporan sustainability report. Variabel ini menggunakan pengukuran sebagai berikut:

$$
\text { Kineria Ekonomi : } \frac{\text { Total Pengungkkapan Sustainability Report Perusahaan sub Kineria Ekonomi }}{\text { Jumlah Indeks Pengungkapan GRI } 2016}
$$

Variabel ini menggunakan skala Rasio.

cKinerja Lingkungan- GRI 300, merupakan pelaporan kinerja ekonomi perusahaan pada laporan sustainability report Variabel ini menggunakan pengukuran sebagai berikut:

$$
\text { Kinerja Lingkungan : } \frac{\text { Total Pengungkapan Sustainability Report Perusahaan sub Kinerja Lingkungan }}{\text { Jumlah Indeks Pengungkapan GRI } 2016}
$$

Variabel ini menggunakan skala Rasio.

dKinerja Sosial- GRI 400, merupakan pelaporan kinerja sosial perusahaan pada laporan sustainability report Variabel ini menggunakan pengukuran sebagai berikut:

$$
\text { Kinerja Sosial : } \frac{\text { Total Pengungkapan Sustainability Report Perusahaan sub Kinerja Sosial }}{\text { Jumlah Indeks Pengungkapan GRI } 2016}
$$

Variabel ini menggunakan skala Rasio.

\section{HASIL DAN PEMBAHASAN}

Statistik Descriptive, Bedasarkan hasil pengujian uji deskrititif yang dilakukan terhadap semua variabel, dengan hasil sebagai berikut:

Tabel 1

\begin{tabular}{lrr|r|r|r} 
& \multicolumn{5}{c}{ Descriptive Statistics } \\
& N & Minimum & Maximum & Mean & Std. Deviation \\
\hline ROA & 60 & .37 & .80 & .4940 & .08567 \\
\hline SR & 60 & .08 & .92 & .3850 & .19195 \\
\hline Ekondand & 60 & .03 & .80 & .3183 & .16426 \\
\hline Linakunaan & 60 & .12 & .77 & .3559 & .13621 \\
\hline Sosial & 60 & .71 & 1.66 & 1.0434 & .17682 \\
\hline Valid N (listwise) & 60 & & & & \\
\hline
\end{tabular}

Hasil Output Software Statistik

Berdasarkan hasil uji statistik deskriptif dimana nilai ROA maximum diperoleh PT Indo Tambangraya Megah pada Tahun 2018 dengan nilai $0.137 \%$ sedangkan nilai minimum diperoleh PT XL Axiata pada tahun 2018 dengan nilai $-0.057 \%$ dan nilai rata-rata $0.028 \%$ untuk perusahaan yang memasuki nominasi ASSRAT selama periode penelitian.

Sosial Responsibility dengan nilai maximum sebesar 0.800 diperoleh PT Timah pada tahun 2018, sedangkan nilai minimum diperoleh Bank Cimb Niaga pada tahun 2017 dengan nilai 0.370 , dan nilai rata-rata pelaporan sustainability report 0.494 dimana perusahaan yang memasuki nominasi ASSRAT telah melaporkan kegiatan sustainability report 50\% dari indikator-indikator yang telah ditentukan oleh Global Reporting Initiative.

Variabel ekonomi memiliki nilai maximum sebesar 0.920 diperoleh PT Perusahaan Gas Negara pada tahun 2019, sedangkan nilai minimum sebesar PT Indo Tambangraya Megah pada tahun 2018 dengan nilai 0.080 dan nilai rata- rata variabel aspek kinerja 
ekoomi sebesar 0.385, yang berarti perusahaan yang memiliki nominasi ASSRAT mengikuti pedoman GRI 200 hanya mampu memenuhi 38.5\% komponen yang termaktub pada GRI 200.

Variabel lingkungan memiliki nilai maximum sebesar 0.800 diperoleh PT Perusahaan Gas Negara pada tahun 2019, sedangkan nilai minimum diperoleh PT XL Axiata pada tahun 2017 dengan nilai 0.030 , dan nilai rata-rata diperoleh sebesar 0.0356 yang berarti perusahaan yang masuk kedalam nominasi ASSRAT hanya melaporkan 3\% dari GRI 400 .

Uji Normalitas, Pengujian dilakukan dengan menggunakan Shapiro-Wilk Test dengan nilai signifikan diatas 0.05 sehingga dapat diasumsikan data memiliki distribusi normal dengan hasil olah data sebagai berikut:

Tabel 2

Uji Kolmogorv-Smirnov

One-Sample Kolmogorov-Smirnov Test

\begin{tabular}{|c|c|c|c|c|c|c|}
\hline & & LNROA & SQRTSR & Ekenomi & Linakungaan & LNSosial \\
\hline N & & 56 & 56 & 56 & 56 & 56 \\
\hline \multirow[t]{2}{*}{ Normal Rarameterera } & Mean & .7321 & .5871 & .3077 & .3456 & .0235 \\
\hline & Std. Deviation & .14490 & . 14158 & 15013 & .12620 & 15514 \\
\hline \multirow[t]{3}{*}{ Most Extreme Differences } & Absolute & .116 & .112 & .083 & .139 & 109 \\
\hline & Positive & .116 & .112 & .083 & .139 & .104 \\
\hline & Negative & -.069 & -.111 & -.070 & -.072 & -109 \\
\hline Test Statistic & & .116 & .112 & .083 & .139 & 109 \\
\hline Asyrod, Sia. (2-tailed) & & $.059^{\circ}$ & $.078^{\circ}$ & $2000 \mathrm{~d}$ & $.008^{\circ}$ & $.093^{\circ}$ \\
\hline \multicolumn{7}{|l|}{ a. Test distribution is Normal. } \\
\hline \multicolumn{7}{|l|}{ b. Calculated from data. } \\
\hline \multicolumn{7}{|c|}{ c. Lilliefors Significance Correction. } \\
\hline \multicolumn{7}{|c|}{ d. This is a lower bound of the true significance. } \\
\hline
\end{tabular}

Hasil Output Software Statistik

\section{Uji Multikolinearitas}

Hasil uji statistik dimana nilai VIF kurang dari 10 dan nilai toleransi kurang dari nilai 1, sehingga data penelitian ini tidak memiliki korelasi dengan hasil statistik berikut:

Tabel 3

Uji Multikolinearitas

\begin{tabular}{|c|c|c|c|}
\hline \multicolumn{4}{|c|}{ Uji Multikolinearitas } \\
\hline \multirow{2}{*}{ Model } & & \multicolumn{2}{|c|}{ Collinearity Statistics } \\
\hline & & Tolerance & VIF \\
\hline \multirow{5}{*}{1} & (Constant) & & \\
\hline & SQRTSR & 0.683 & 1.465 \\
\hline & Eksoomi & 0.711 & 1.406 \\
\hline & Lingkungan & 0.575 & 1.741 \\
\hline & LNSosial & 0.814 & 1.228 \\
\hline
\end{tabular}

a. Dependent Variable: LNROA

Hasil Output Software Statistik

Uji Autokorelasi, Dari hasil uji statistik diatas ditemukan angka Durbin Watson (d) sebesar 1,836 > dari batas atas (dU) yakni dengan nilai 1,7246 dan < dari (4-dU) 4-1,7246 $=2,2574$. Hasil tersebut disimpulkan tidak ada masalah atau gejala autokorelasi pada penelitian ini. Maka untuk uji hipotesis penelitian analisis regresi linear berganda ini dapat dilanjutkan, dengan detail hasil statistik sebagai berikut:

Tabel 4

Uji Autokorelasi 


\begin{tabular}{lc|c|c|c|c} 
Model & $\mathrm{R}$ & $\begin{array}{c}\mathrm{R} \\
\text { Square }\end{array}$ & $\begin{array}{c}\text { Adjusted } \\
\mathrm{R} \\
\text { Square }\end{array}$ & $\begin{array}{c}\text { Std. } \\
\text { Error of } \\
\text { the } \\
\text { Estimate }\end{array}$ & $\begin{array}{c}\text { Durbin- } \\
\text { Watson }\end{array}$ \\
\hline 1 & $.919^{\mathrm{a}}$ & 0.844 & 0.832 & 0.05943 & 1.836 \\
\hline $\begin{array}{l}\text { a. Predictors: (Constant), LNSosial, SQRTSR, Ekenomi, Lingkungaan } \\
\text { b. Dependent Variable: LNROA }\end{array}$ \\
Hasil Output Software Statistik
\end{tabular}

Uji Heterokedastisitas, Penelitian Heterokedastisitas ini memberikan informasi perubahan suatu variabel yang dapat memperoleh informasi perubahan atau variasi pada variabel lainnya (Hermanto, 2018). Nilai pada uji ini menggunakan nilai 0 dan 1, jika hasil uji mendekati nilai 0 yang menginformasikan kemampuan atas suatu variabel bebas dapat menginformasikan variabel bebas memiliki keterbatasan. Akan tetapi jika nilai mendekati angka 1 berarti variabel bebas menginformasikan semua informasi yang dibutuhkan pada uji ini dapat memprediksi variasi variabel terikat. Berdasarkan hasil uji statistik data yang diteliti menyebar dengan nilai antara 0 dan 1, dengan gambar sebagai berikut:

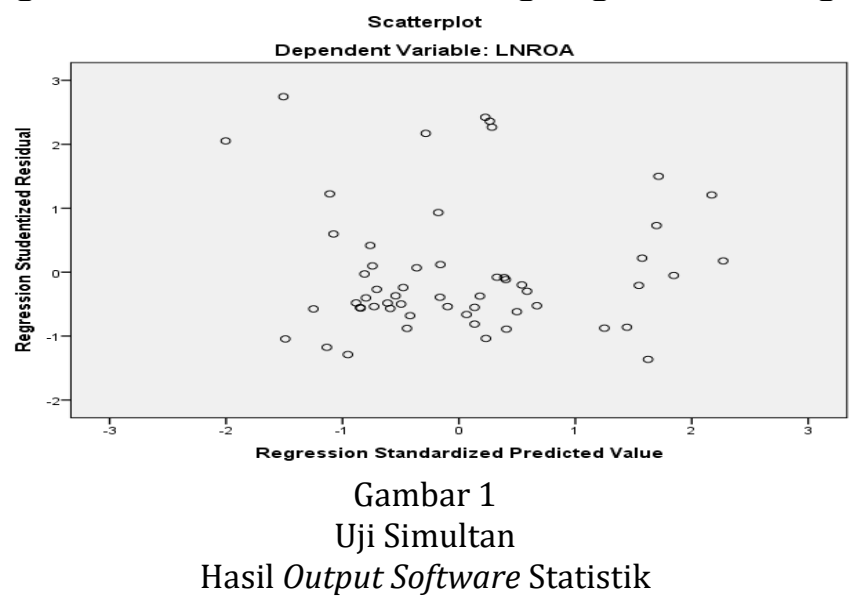

Hasil tabel output uji statistik diketahui nilai signifikan adalah sebesar 0,000 berarti dibawah 0,05, dapat ditarik kesimpulan Social Responsibility, Ekonomi, Lingkungan dan Sosial secara simultan menunjukkan pengaruh terhadap Return on Asset dan maka $\mathrm{H}_{1}$ diterima yang menyatakan Social Responsibility, Ekonomi, Lingkungan dan Sosial memiliki pengaruh secara bersama-sama terhadap ROA, dengan detail tabel sebagai berikut:

Tabel 5

Uji Simultan

\begin{tabular}{|c|c|c|c|c|c|c|}
\hline \multicolumn{7}{|c|}{ ANOVAa } \\
\hline Model & & Sum of Squares & $\mathrm{df}$ & Mean Square & $\mathrm{F}$ & Siq. \\
\hline \multirow[t]{3}{*}{1} & Regression & .975 & 4 & 244 & 68.981 & $.000^{\mathrm{b}}$ \\
\hline & Residual & 180 & 51 & .004 & & \\
\hline & Total & 1.155 & 55 & & & \\
\hline \multicolumn{7}{|c|}{ a. Dependent Variable: LNROA } \\
\hline \multicolumn{7}{|c|}{ b. Predictors: (Constant), LNSosial, SQRTSR, Ekonomi, Lingkungan } \\
\hline \multicolumn{7}{|c|}{ Hasil Output Software Statistik } \\
\hline
\end{tabular}




\section{Uji Parsial}

Berdasarkan hasil pengolahan statistik dibawah ini:

Tabel 6

Uji Parsial

\begin{tabular}{|c|c|c|c|c|c|c|c|c|}
\hline \multirow[b]{2}{*}{ Model } & & \multicolumn{2}{|c|}{ Unstandardized Coefficients } & \multirow{2}{*}{$\begin{array}{c}\text { Standardized } \\
\text { Coefficients } \\
\text { Beta } \\
\end{array}$} & \multirow[b]{2}{*}{$t$} & \multirow[b]{2}{*}{ Sig. } & \multicolumn{2}{|c|}{ Collinearity Statistics } \\
\hline & & B & Sttd. Error & & & & Tolerance & VIF \\
\hline 1 & (Constant) & -1.164 & .041 & & -28.466 & .000 & & \\
\hline & SQRTSR & 135 & .069 & .132 & 1.973 & .054 & .683 & 1.465 \\
\hline & Ekonomi & .499 & .063 & .517 & 7.887 & .000 & .711 & 1.406 \\
\hline & Lingkungan & .583 & .084 & .508 & 6.956 & .000 & .575 & 1.741 \\
\hline & LNososial & .097 & .057 & .104 & -1.693 & .097 & .814 & 1.228 \\
\hline
\end{tabular}

Hasil Output Software Statistik

Berdasarkan hasil dari diatas dapat dijelaskan sebagai berikut:

Pengaruh Sustainability report, Aspek kinerja ekonomi, Aspek kinerja lingkungan, dan Aspek kinerja sosial terhadap Return on Asset.

Berdasarkan hasil uji Simultan dimana variabel Sustainability report, economic performance, environment performance, dan social performance mampu mempengaruhi performance perusahaan dimana pengungkapan laporan yang transparan dapat menaikan produktivitas tenaga kerja, tingkat kepercayaan konsumen dan kepercayaan invenstor sehingga perusahaan dapat menghasilkan keuntungan perusahaan yang baik.

\section{Hubungan antara Sustainability Report dengan Return on Asset}

Berdasarkan pengujian atas variabel independent diperoleh sustainability report tidak memiliki pengaruh terhadap Return on Asset pada perusahaan yang telah masuk kedalam nominasi ASSRAT dalam menjalankan bisnisnya perusahaan tetap memperhatikan aspek- aspek dalam sustainability report namun pada pelaksanaan tersebut tidak menganggu kinerja perusahaan dalam menghasilkan keuntungan perusahaan. Dalam satu sisi penerapan pada perusahaan yang telah masuk dalam nominasi ASSRAT hanya melaporkan 38.50\% pengungkapan sustainability report. Perusahaan tersebut tidak terlalu memprioritaskan laporan sustainability report dan lebih berfokus pada keuntungan perusahaan, hal ini menolak penelitian yang telah dilakukan dari Sari \& Wahyuningtyas, (2020), bahwa pengungkapan aspek environment performance dalam Sustainability Report berpengaruh kepada nilai perusahaan. Namun penelitian ini mendukung hasil penelitian dari Sejati \& Prastiwi, (2015).

\section{Hubungan antara Aspek kinerja ekonomi dengan Return on Asset}

Hasil olah data yang diperoleh bahwa kinerja ekonomi dapat mempengaruhi Return on Asset perusahaan yang masuk kedalam nominasi ASSRAT. Hal ini pengungkapan aspek kinerja Ekonomi perusahaan dapat mendorong investor melakukan investasi pada suatu entitas dalam hal ini mendapatkan modal tambahan untuk melakukan proses pendanaan terutama pada asset perusahaan untuk menunjang kegiatan operasional perusahaan sehingga mampu memberikan kontribusi pendapatan yang lebih baik. Hal ini tercermin investor di Indonesia cenderung menyukai perusahaan yang mengunggkapkan laporanlaporan perusahaan yang secara transparan. Hal ini mendukung penelitian Nelmida et al., (2020) pengungkapan economic performance memiliki dampak positif atas financial performance perusahaan. Hal ini tidak sejalan atas hasil penelitian Tarigan \& Semuel, (2014) yakni kinerja aspek ekonomi dari Sustainability Report tidak memiliki dampak terhadap financial performance. 


\section{Hubungan antara aspek kinerja lingkungan dengan Return on Asset}

Hasil olah data menunjukan terdapat pengaruh hubungan kinerja lingkungan terhadap Return on Asset. Pengungkapan laporan sustainability report dengan sub kinerja lingkungan dilakukan perusahaan mampu dapat memberikan bukti empiris atas proses operasional perusahaan tidak memprioritaskan keuntungan semata tetapi tetap memperhatikan kondisi lingkungan sekitar perusahaan sehingga dapat meningkatkan citra perusahaan dimata stakeholders sehingga investor dan stakeholders lainnya memiliki tingkat kepercayaan yang tinggi terhadap perusahaan sehingga mampu meningkatkan peningkatan laba perusahaan. Hal ini sejalan dengan penelitian Wijayanti, (2020) dan menolak penelitian Wibowo \& Faradiza, (2014).

\section{Hubungan Aspek kinerja sosial dengan Return on Asset}

Hasil olah data menunjukan tidak terdapat pengaruh kinerja sosial terhadap Return on Asset. Pengungkapan tanggung jawab sosial dilingkungan internal perusahaan tidak dapat mendorong respon stakeholders didalam perusahaan dimana stakeholders internal perusahaan seperti karyawan tidak terlalu memperdulikan pengungkapan laporan pada lingkungan internal perusahaan. Dimana tenaga kerja hanya lebih tertarik dengan kompensasi dan fasilitas yang diberikan perusahaan terhadap dirinya. Hal ini todak sejalan dengan penelitian Yuliani \& Taringan: 2014 menyatakan aspek kinerja perusahaan berpengaruh terhadap kinerja perusahaan.

Implikasi Penelitian, Perusahaan yang masuk kedalam nominasi ASSRAT belum secara transparan dalam pelaporan sustainability report dimana hasil penelitian ini hanya $38.50 \%$ perusahaan yang melaporkan laporan sustainability report secara transapran dan $71.50 \%$ belum secara transparan dalam menginformasikan laporan Sustainability reporting.

\section{Koeifisien Determinasi $\left(\mathrm{R}^{2}\right)$}

Uji koefisien determinasi menginformasikan kemampuan model dapat menerangkan varian dengan variabel terikat. Nilai R-squared kecil menginformasikan kapasitas atas variabel bebas dalam menginformasikan varian variabel terikat memiliki keterbatasan (Ghozali, 2017). Nilai mendekati angka 1 berarti varian variabel bebas mampu memberikan semua keterangan yang dibutuhkan untuk dapat memperkirakan varian variabel bebas. Hasil uji statistik koefisien determinasi terlihat Tabel 7:

Tabel 7. Uji Adjusted $\mathbf{R}^{2}$

\begin{tabular}{|c|c|c|c|c|c|}
\hline \multirow[b]{2}{*}{ Model } & \multirow[b]{2}{*}{$\mathrm{R}$} & & \multirow[b]{2}{*}{ Durbin-Watson } \\
\hline & & R Square & $\begin{array}{c}\text { Adjusted R } \\
\text { Square }\end{array}$ & $\begin{array}{c}\text { Std. Error of the } \\
\text { Estimate }\end{array}$ & \\
\hline 1 & $.919^{a}$ & .844 & .832 & .05943 & 1.836 \\
\hline \multicolumn{6}{|c|}{ a. Predictors: (Constant), LNSosial, SQRTSR, Ekonomi, Lingkungan } \\
\hline \multicolumn{6}{|c|}{ b. Dependent Variable: LNROA } \\
\hline \multicolumn{6}{|c|}{ Hasil Output Software Statistik } \\
\hline
\end{tabular}

Berdasarkan hasil tabel uji koefisien determinasi diperoleh nilai Adjusted $\mathrm{r}^{2}$ dengan nilai 0.832 atau $83.2 \%$ variabel Sustainability Report, economic, environment, dan social dapat memberikan kontribusi terhadap financial performance perusahaan yang di proxykan dengan Return on Asset.

Uji Regresi Linear Berganda, Berdasarkan hasil olah data statistik diperoleh nilai beta untuk Social Responsibility dengan nilai beta sebesar 0.135, Kinerja Ekonomi sebesar 0.499, Kinerja Lingkungan sebesar 0.583, Kinerja Sosial sebesar -0.907 , constanta sebesar -1.164 dan nilai error sebesar -0.041 dan hasil dari ROA yang didapatkan dengan 
menjumlah nilai beta masing- masing nilai beta masing- masing variabel independen sebesar -0.895 dengan perhitungan sebagai berikut:

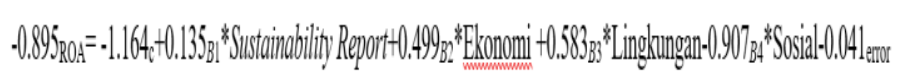

\section{SIMPULAN}

Perusahaan yang masuk dalam nominasi ASSRAT lebih memperhatikan aspek Kinerja Ekonomi diperusahaan sehingga paradigma old Corporate Relation masih diadopsi oleh perusahaan- perusahaan yang masuk nominasi ASSRAT. Perusahaan pada nominasi ASSRAT tidak hanya memperhatikan keuntungan semata namun tetap memberikan perhatian kepada aspek kinerja lingkungan sehingga dapat meningkatkan image perusahaan dimata stakeholders. Hal ini perlu dilakukan/ penerapan monitoring yang ketat terhadap penerapan pelaporan sustainability report dan pemenuhan secara aspeknya dan membuatkan seperangkat aturan untuk perusahaan yang belum go public, sehingga dapat mengantisapasi segala risiko yang dihadapi dan mampu memberikan kontribusi/ sumbangsih kepada negara. Sedangkan pengungkapan Sustainability Report mampu menarik investor untuk menginvestasikan modal yang dimilikinya terhadap perusahaan yang memberikan laporan- laporan secara transaparan. Tipikal investor di Indonesia lebih menyukai transparansi perusahaan dalam memberikan laporan kepada investor sehingga investor mampu dapat menilai kinerja perusahaan dengan seksama.

\section{DAFTAR PUST AKA}

Ardiyasa, I. P. (2021). Strategi Peningkatan StakeholderBaru Organisasi Seni Pertunjukan. Jurnal Tata Kelola Seni, 7(1). https://journal.isi.ac.id/index.php/JTKS/article/view/4205/2154

Burlea, A. S., \& Popa, I. (2013). Legitimacy Theory. Encyclopedia of Corporate Social Responsibility, 15791584.

Chariri, A., \& Ghozali, I. (2007). Teori Akuntansi. Badan Penerbit Universitas Diponegoro.

Deegan, C., \& Unerman, J. (2006). Financial Accounting Theory European Edition (Berkshire (ed.)). McGrawHILL Education.

Eliyana, \& Subakir. (2020). Pengungkapan Substainability Report Terhadap Return on Assets (ROA) Perusahaan Manufaktur Bidang Pertambangan. Majalah Ekonomi Dan Bisnis Universitas PGRI Adi Buana Surabaya, 25.

Elkington, J. (1997). Cannibals With Forks: The Triple Bottom Line of 21st Century (Capstone (ed.)). Oxford.

Ernst \& Young. (2014). Sustainability Reporting - The Time is Now. EY.Com.

Ernst \& Young Global Limited. (2013). Value of Sustainability Reporting. A study by Ernst \& Young LLP and the Boston College Center for Corporate Citizenship.

Ghozali, I. (2017). Aplikasi Analisis Multivariete SPSS 25 Edisi 9 (3rd ed.). Badan Penerbit Universitas Diponegoro.

GRI. (2016). Global Reporting Initiative 2016. Website.

Hadi, N. (2009). Responsibility: Kajian Theoritical Framework Dan Perannya Dalam Riset Di Bidang Akuntansi. Jurnal Ekonomi Dan Bisnis Sekolah Tinggi Agama Islam Negeri Kudus, 4.

Hermanto. (2018). Jurnal Akuntansi Bisnis. Analisis Pembagian Deviden Pada Perusahaan Yang Tercatat Di BEI, 11(1), 41-53.

Kompas.com. (2015). Penting, Laporan Keberlanjutan Perusahaan Sebagai Kewajiban.

Lee, S. W. A. (2017). Relationship Between Quality of Sustainability Report and Corporate Financial Performance. Journal Faculty of Business and Law University of Newcastle Australia.

Lindblom. (1994). The Implications of Organizational Legitimacy for Corporate Social Performance and Disclosure. Paper Presented at the Critical Perspectives on Accounting Conference.

Manik, K. E. S. (2016). Pengelolaan Lingkungan Hidup. Kencana.

Mulyaningsih, \& Hermina, T. (2017). Etika Bisnis (N. Kania (ed.); 1st ed.). Kimfa Mandiri. 
Nelmida, Tahun, A. M., Risa, A. H., \& Krisdatama, K. (2020). The Impact of Substainability Reporting on Company Performance. International Journal of Business and Economy Management Department STIE Indonesia Banking School Jakarta, 2(3), 9-25.

Neu, D., Warsame, H., \& Pedwell, K. (1998). Managing Public Impressions: Environmental Disclosures in Annual Reports. Accounting, Organizations and Society Elsevier Science Ltd, 23(3), 265-282.

OJK. (2017). POJK Nomor 51/POJK.03/2017. Otoritas Jasa Keuangan.

Porter, M. E., \& Kramer, M. R. (2006). Strategy \& Society: The Link Between Competitive Advantage and Corporate Social Responsibility. Harvard Business Review. https://doi.org/10.1108/sd.2007.05623ead.006

Sari, N. R., \& Wahyuningtyas, E. T. W. E. T. (2020). Studi Penerapan Green Accounting dan Pengungkapan Sustainability Reporting Terhadap Profitabilitas. NATIONAL CONFERENCE FOR UMMAH (NCU), 1(1).

Sejati, B. P., \& Prastiwi, A. (2015). Pengaruh Pengungkapan Sustainability Report Terhadap Kinerja dan Nilai Perusahaan. Diponegoro Journal of Accounting, 195-206.

UN Global Compact. (2019). Guide for General Counsel on Corporate Sustainability Version 2.0. United Nations Global Compact.

Wahab. (2020). Pengaruh Program Linkage Terhadap Sustainabilitas Usaha Pada Lembaga Keuangan Mikro Syari'ah. Universitas Islam Indonesia.

Wibowo, I., \& Faradiza, S. A. (2014). Dampak Pengungkapan Sustainability Report Terhadap Kinerja Keuangan dan Pasar Perusahaan. Jurnal Akuntansi Universitas Teknologi Yogyakarta.

Wijayanti, R. (2020). Pengaruh Pengungkapan Substainability Report Terhadap Kinerja Keuangan Perusahaan. Seminar Nasional Dan The 3rd Call for Syariah Paper Universitas Muhammadiyah Surakarta, 59(1), 4-21. https://doi.org/10.1177/002795017205900102

Yuliani, L., \& Taringan, J. (2014). Pengaruh Sustainability Reporting Terhadap Kinerja Keuangan Perusahaan Publik dari Sisi Asset Management Ratios. Business Accounting Review, 2(1), 101-110.

Zelditch Jr, M. (2018). Legitimacy Theory. Stanford University Press. 